\title{
Fodinibius salinus gen. nov., sp. nov., a moderately halophilic bacterium isolated from a salt mine
}

\author{
Correspondence \\ Xiao-Long Cui \\ xlcuiynu@yahoo.com.cn, \\ xlcui@ynu.edu.cn
}

\author{
Yong-Xia Wang, ${ }^{1} \dagger$ Ji-Hui Liu, ${ }^{1} \dagger$ Wei Xiao, ${ }^{1}$ Xiao-Xia Zhang, ${ }^{2}$ Yi-Oing Li, \\ Yong-Hong Lai, ${ }^{1}$ Kai-Yan Ji, ${ }^{1}$ Meng-Liang Wen ${ }^{1}$ and Xiao-Long Cui ${ }^{1}$
}

\author{
${ }^{1}$ The Key Laboratory for Microbial Resources of the Ministry of Education, \\ and Laboratory for Conservation and Utilization of Bio-Resources, \\ Yunnan Institute of Microbiology, Yunnan University, Kunming, Yunnan 650091, PR China \\ ${ }^{2}$ Agricultural Cultural Collection of China, Institute of Agricultural Resources and Regional Planning, \\ Chinese Academy of Agricultural Sciences, Beijing 100080, PR China
}

The taxonomy of the large group of bacteria formerly classified as the Cytophaga-Flavobacterium-Bacteroides group (Olsen et al., 1994) is in need of clarification. Stoecker et al. (2006), for example, presented molecular evidence that indicated that the genus Crenothrix belonged to the order Methylococcales of the class Gammaproteobacteria. Consequently, other genera originally assigned to the family Crenotrichaceae within the order Sphingobacteriales are currently considered Sphingobacteriales genera incertae sedis. Such genera include Rhodothermus (Alfredsson et al., 1988; Sako et al., 1996) and Salinibacter (Antón et al., 2002), both of which include species that

TThese authors contributed equally to this work.

Abbreviations: AL, aminolipid; DPG, diphosphatidylglycerol; GL, glycolipid; L, polar lipid; PC, phosphatidylcholine; PE, phosphatidylethanolamine; PL, phospholipid.

The GenBank/EMBL/DDBJ accession number for the 16S rRNA gene sequence of strain YIM D $17^{\top}$ is HM153810.

Three supplementary figures are available with the online version of this paper. show extremophilic characteristics: Rhodothermus strains are thermophilic whereas strains of the genus Salinibacter are extreme halophiles. Recently, two new genera that were phylogenetically related to the genera Rhodothermus and Salinibacter were described and named Balneola (Urios et al., 2006) and Gracilimonas (Choi et al., 2009), respectively. These two genera, which were both isolated from seawater, do not exhibit any of the extreme features found in species of the genera Rhodothermus and Salinibacter. In this paper, the characterization and classification of a strain (from the phylum Bacteroidetes) that appears taxonomically novel at the genus level are reported.

During an investigation of the microbial diversity of the hypersaline environments in Yunnan, south-western China, strain YIM $D 17^{\mathrm{T}}$ was isolated from a sediment sample (with $49.3 \%$, w/v, $\mathrm{NaCl}$ ) collected from the Fenggang salt mine $\left(23^{\circ} 28^{\prime} \mathrm{N} 100^{\circ} 43^{\prime} \mathrm{E}\right)$. The strain was isolated at $37^{\circ} \mathrm{C}$, by the standard dilution-plating technique, on marine agar 2216 (MA; Difco) supplemented with $10 \%(\mathrm{w} / \mathrm{v}) \mathrm{NaCl}$ (modified MA). It was subsequently maintained on modified MA slants, and preserved at 
$-80{ }^{\circ} \mathrm{C}$ as a suspension in distilled water containing $20 \%$ (v/v) glycerol.

Gram staining was carried out using the standard Gram reaction combined with $\mathrm{KOH}$ lysis (Gregersen, 1978). Cell morphology and flagella were examined by light microscopy (BH-2; Olympus) after Leifson staining (Murray et al., 1994). Growth at various temperatures $(4,10,15,20$, $25,28,37,45,50,55$ and $\left.60{ }^{\circ} \mathrm{C}\right)$ and $\mathrm{pH}$ values $(4.0-11.0$, in increments of $0.5 \mathrm{pH}$ unit, at $37^{\circ} \mathrm{C}$ ) was assessed on marine broth 2216 (MB; Difco) supplemented with $10 \%$ (w/v) $\mathrm{NaCl}$ (modified $\mathrm{MB}$ ). To test $\mathrm{NaCl}$ tolerance, growth on nutrient agar (Difco) and tryptone soy agar (TSA; BD), each containing no $\mathrm{NaCl}$ or $1,3,4,5,7,8,10,12,15,20,21$, $22,23,24,25$ or $30 \%(w / v) ~ N a C l$, was investigated at $37{ }^{\circ} \mathrm{C}$. Growth under anaerobic conditions was explored by incubation on modified MA in an anaerobic jar (GasPak anaerobic systems; BBL). Accumulation of poly- $\beta$-hydroxybutyrate was observed by Sudan black staining (Smibert \& Krieg, 1994) under a light microscope. Bacteriochlorophyll $a$ was analysed spectrophotometrically by using the method of Cohen-Bazire et al. (1957) and following the recommendations of Allgaier et al. (2003). Catalase and oxidase activities were determined using $3 \%(\mathrm{v} / \mathrm{v}) \mathrm{H}_{2} \mathrm{O}_{2}$ and Kovacs' reagent (Kovacs, 1956), respectively. Glucose fermentation, arginine dihydrolase, indole production, $\beta$-galactosidase and urease activities, and hydrolysis of aesculin, casein, DNA, gelatin, starch, Tween 40 and Tween 80 were examined as described by Hansen \& Sørheim (1991). Nitrate reduction was tested in modified $\mathrm{MB}$ medium containing $0.2 \% \mathrm{KNO}_{3}$. Nitrite was monitored with the naphthylamine/sulphanilic acid reagent, and residual nitrate with zinc powder; gas production was detected in Durham tubes. $\mathrm{H}_{2} \mathrm{~S}$ production was tested in modified MB supplemented with $0.01 \%$ (w/v) L-cysteine; the indicator (a strip of paper impregnated with lead acetate) was placed in the neck of the culture tube. Other enzyme activities were assayed by using the API ZYM kit (bioMérieux) according to the manufacturer's instructions, and cells suspended in autoclaved saline containing $10 \%$ $(\mathrm{w} / \mathrm{v}) \mathrm{NaCl}$. To explore carbon utilization, a potential carbon source, at a final concentration of $0.5 \%(\mathrm{w} / \mathrm{v}$ or $\mathrm{v} / \mathrm{v})$, was added to a basal medium of artificial seawater (Cho \& Giovannoni, 2006) (without $\mathrm{NH}_{4} \mathrm{Cl}$ if an amino acid was being tested) supplemented with $10 \%(\mathrm{w} / \mathrm{v}) \mathrm{NaCl}$. Antibiotic sensitivity was explored by placing commercial antibiotic discs (HiMedia) on modified MA plates that had been spread with the isolate and then incubating at $37{ }^{\circ} \mathrm{C}$ for 5 days.

Polar lipids of strain YIM $\mathrm{D} 17^{\mathrm{T}}$, Gracilimonas tropica DSM $19535^{\mathrm{T}}$, Balneola vulgaris DSM $17893^{\mathrm{T}}$ and Balneola alkaliphila DSM $19538^{\mathrm{T}}$ (Urios et al., 2008) were extracted (Minnikin et al., 1979) and identified by two-dimensional TLC (Collins \& Jones, 1980). Isoprenoid quinones of these four strains were also extracted (Collins et al., 1977) and analysed by HPLC (Tamaoka et al., 1983). Biomass for the quantitative analysis of fatty acids was obtained by scraping cells from cultures of strain YIM D17 $7^{\mathrm{T}}$ (grown on modified MA for 7 days at $37^{\circ} \mathrm{C}$ ), Gracilimonas tropica DSM $19535^{\mathrm{T}}$, Balneola vulgaris DSM $17893^{\mathrm{T}}$ and Balneola alkaliphila DSM $19538^{\mathrm{T}}$ (all grown on MA for 3 days at $28{ }^{\circ} \mathrm{C}$ ), Salisaeta longa DSM $21114^{\mathrm{T}}$ (grown on DSMZ 1221 medium for 3 days at $37{ }^{\circ} \mathrm{C}$ ), Rhodothermus profundi DSM $22212^{\mathrm{T}}$ (grown on MA at $65{ }^{\circ} \mathrm{C}$ for 2 days) and Rhodothermus marinus DSM $4252^{\mathrm{T}}$ (grown on DSMZ 630 medium at $65{ }^{\circ} \mathrm{C}$ for 2 days). Analysis of the cellular fatty acid pattern followed the method described by Sasser (1990) but used version 6.0 of the Sherlock Microbial Identification System (MIDI, 2005).

Genomic DNA extraction, PCR amplification of the $16 \mathrm{~S}$ rRNA gene, and sequencing of the purified PCR product were carried out as described previously (Cui et al., 2001). The sequenced length of the 16S rRNA gene of strain YIM $\mathrm{D} 17^{\mathrm{T}}$ was $1466 \mathrm{bp}$. The $16 \mathrm{~S}$ rRNA gene sequences of the closely related taxa were retrieved from the GenBank database using BLAST (Altschul et al., 1997) before all the sequences were aligned and the levels of similarity were calculated using CLUSTAL_X (Thompson et al., 1997). Phylogenetic trees were constructed using the neighbourjoining (Saitou \& Nei, 1987) and maximum-parsimony (Fitch, 1971) methods, in MEGA version 4 (Tamura et al., 2007), while a maximum-likelihood (Felsenstein, 1981) tree was generated using the treeing algorithm contained in the PHYLIP package (Felsenstein, 1993). Evolutionary distances for the neighbour-joining tree were calculated by using the Kimura two-parameter model (Kimura, 1980). Bootstrap analysis with 1000 resamplings (Felsenstein, 1985) was used to evaluate tree topology.

The cells of strain YIM D $17^{\mathrm{T}}$ were Gram-stain-negative, catalase- and oxidase-positive, straight or slightly curved rods, $0.3 \mu \mathrm{m}$ wide and 1.0-3.0 $\mu \mathrm{m}$ long (see Supplementary Fig. S1, available in IJSEM Online). Neither flagella nor endospores were observed. Growth occurred on nutrient agar supplemented with $4-23 \%(\mathrm{w} / \mathrm{v}) \mathrm{NaCl}$ (but not on TSA supplemented with various concentrations of $\mathrm{NaCl}$ ). After growth on modified MA or on nutrient agar supplemented with $10 \%(\mathrm{w} / \mathrm{v}) \mathrm{NaCl}$, at $37{ }^{\circ} \mathrm{C}$ for 7 days, colonies were pink, circular, convex and translucent, with regular margins. The temperature range for growth was 25$45{ }^{\circ} \mathrm{C}$ while the $\mathrm{pH}$ range for growth at $37{ }^{\circ} \mathrm{C}$ was 6.0-9.0. The isolate was sensitive to ampicillin $(10 \mu \mathrm{g})$, erythromycin $(15 \mu \mathrm{g})$ and chloramphenicol $(30 \mu \mathrm{g})$, and resistant to gentamicin $(10 \mu \mathrm{g})$, penicillin $\mathrm{G}(20 \mathrm{U})$, streptomycin $(10 \mu \mathrm{g})$, norfloxacin $(10 \mu \mathrm{g})$, carbenicillin $(100 \mu \mathrm{g})$ and ciprofloxacin $(5 \mu \mathrm{g})$. Phenotypically, the novel isolate differed from the recognized species to which it was most closely related (G. tropica, B. vulgaris and B. alkaliphila) in several features (Table 1). Other phenotypic characteristics of strain YIM $\mathrm{D} 17^{\mathrm{T}}$ are given in the species description.

The $\mathrm{G}+\mathrm{C}$ content of the DNA of strain YIM D $17^{\mathrm{T}}$, extracted according to the method of Cui et al. (2001), was determined to be $43.0 \mathrm{~mol} \%$ by HPLC (Mesbah et al., 1989), with the DNA of Escherichia coli DH5 $\alpha$ used as a standard.

Although strain YIM D $17^{\mathrm{T}}$ and G. tropica DSM $19535^{\mathrm{T}}$ shared some major polar lipids, differences in their lipid 
Table 1. Characteristics that distinguish strain YIM D17 ${ }^{\top}$ from closely related, recognized species

Strains: 1, YIM D17 $7^{\mathrm{T}}$ (data from this study); 2, Gracilimonas tropica DSM $19535^{\mathrm{T}}$ (this study); 3, Balneola vulgaris DSM $17893^{\mathrm{T}}$ (this study); 4, Balneola alkaliphila DSM $19538^{\mathrm{T}}$ (this study); 5 , Salisaeta longa S4-4 ${ }^{\mathrm{T}}$ (Vaisman \& Oren, 2009); 6, Salinibacter ruber M31 (Antón et al., 2002); 7, Rhodothermus marinus DSM 4252 ${ }^{\mathrm{T}}$ (Alfredsson et al., 1988; Sako et al., 1996; Marteinsson et al., 2010); 8, Rhodothermus profundi PRI $2902^{\mathrm{T}}$ (Marteinsson et al., 2010). +, Positive; w, weakly positive; -, negative; ND, no data available.

\begin{tabular}{|c|c|c|c|c|c|c|c|c|}
\hline Characteristic & 1 & 2 & 3 & 4 & 5 & 6 & 7 & 8 \\
\hline Colony colour & Pink & Pale pink & Orange & Pale yellow & Red & Red & Reddish & None \\
\hline Cell shape & Rods, slightly curved & Long irregular rods & Rods & Rods & Rods, slightly curved & Rods, slightly curved & Rods & Rods \\
\hline Motility & - & - & + & - & - & + & + & - \\
\hline $\begin{array}{l}\text { Salinity range for growth } \\
(\% \mathrm{NaCl})\end{array}$ & $5-20$ & $1-20$ & $1-8$ & $1-7$ & $5-20$ & $15-30$ & $1-6$ & $1-5$ \\
\hline $\begin{array}{l}\text { Temperature range for growth } \\
\left({ }^{\circ} \mathrm{C}\right)\end{array}$ & $25-45$ & $20-37$ & $10-45$ & $15-37$ & $25-50$ & $27-52$ & $50-85$ & $55-80$ \\
\hline $\mathrm{pH}$ range for growth & $6.0-9.0$ & $6.0-9.0$ & $6.0-10.0$ & $7.0-9.0$ & $6.0-9.0$ & $6.0-8.5$ & $5.5-9.0$ & $6.0-8.0$ \\
\hline Nitrate reduced to nitrite & + & - & - & - & - & ND & ND & $\mathrm{ND}$ \\
\hline Glucose fermentation & - & + & - & - & ND & ND & $\mathrm{ND}$ & $\mathrm{ND}$ \\
\hline \multicolumn{9}{|l|}{ Hydrolysis of: } \\
\hline Aesculin & + & + & - & - & ND & $\mathrm{ND}$ & $\mathrm{ND}$ & $\mathrm{ND}$ \\
\hline Gelatin & + & + & - & - & $\mathrm{W}$ & + & $\mathrm{ND}$ & $\mathrm{ND}$ \\
\hline Starch & - & + & - & + & $\mathrm{W}$ & + & $\mathrm{ND}$ & $\mathrm{ND}$ \\
\hline Tween 40 & + & + & - & + & ND & $\mathrm{ND}$ & $\mathrm{ND}$ & $\mathrm{ND}$ \\
\hline Tween 80 & + & + & - & - & ND & $\mathrm{ND}$ & $\mathrm{ND}$ & $\mathrm{ND}$ \\
\hline \multicolumn{9}{|l|}{ Utilization of: } \\
\hline Acetate & - & - & + & + & $\mathrm{ND}$ & - & + & - \\
\hline Adenine & - & - & + & - & $\mathrm{ND}$ & $\mathrm{ND}$ & $\mathrm{ND}$ & $\mathrm{ND}$ \\
\hline D-Glucose & - & + & + & - & + & - & + & - \\
\hline Hypoxanthine & - & - & + & + & ND & $\mathrm{ND}$ & $\mathrm{ND}$ & $\mathrm{ND}$ \\
\hline myo-Inositol & - & + & + & + & ND & $\mathrm{ND}$ & $\mathrm{ND}$ & - \\
\hline Maltose & - & + & - & - & + & - & + & - \\
\hline D-Mannitol & - & + & + & + & - & - & $\mathrm{ND}$ & - \\
\hline D-Sorbitol & - & - & + & - & - & - & $\mathrm{ND}$ & - \\
\hline Sucrose & - & - & + & + & + & - & + & - \\
\hline \multicolumn{9}{|l|}{ Enzymic activities (API ZYM): } \\
\hline Esterase (C4) & - & + & + & + & ND & ND & $\mathrm{ND}$ & $\mathrm{ND}$ \\
\hline Trypsin & - & - & + & - & ND & $\mathrm{ND}$ & $\mathrm{ND}$ & $\mathrm{ND}$ \\
\hline$\alpha$-Chymotrypsin & - & + & + & + & $\mathrm{ND}$ & $\mathrm{ND}$ & $\mathrm{ND}$ & $\mathrm{ND}$ \\
\hline Acid phosphatase & - & - & + & + & ND & ND & ND & $\mathrm{ND}$ \\
\hline$N$-Acetyl- $\beta$-glucosaminidase & + & + & - & - & ND & ND & ND & ND \\
\hline Major polar lipids & $\begin{array}{c}\text { DPG, PE, PC, PG, GL, } \\
\text { AL, PL, L }\end{array}$ & $\begin{array}{l}\text { DPG, PE, PG, } \\
\text { PC, GL, PL, L }\end{array}$ & $\begin{array}{l}\text { DPG, PE, } \\
\text { PG, GL, L }\end{array}$ & $\begin{array}{l}\text { DPG, PE, PG, } \\
\text { GL, AL, L }\end{array}$ & $\begin{array}{c}\text { GL, phospholipids } \\
\text { (no unambiguous } \\
\text { phospholipids detected) }\end{array}$ & $\begin{array}{c}\text { GL, phospholipids } \\
\text { (no unambiguous } \\
\text { phospholipids detected) }\end{array}$ & $\begin{array}{l}\text { DPG, PE, } \\
\text { PG, GL, PL }\end{array}$ & $\begin{array}{l}\text { DPG, PE, } \\
\text { PG, GL, PL }\end{array}$ \\
\hline DNA G $+\mathrm{C}$ content $(\mathrm{mol} \%)$ & 43.0 & 42.3 & 41.7 & 39.5 & 62.9 & 66.5 & 64.4 & 60.9 \\
\hline
\end{tabular}


profiles enabled these two strains to be distinguished (Table 1). Major polar lipid components of strain YIM D17 ${ }^{\mathrm{T}}$ (see Supplementary Fig. S2) were diphosphatidylglycerol (DPG), phosphatidylcholine (PC), phosphatidylethanolamine (PE), one unknown phospholipid (PL1), one unknown glycolipid (GL) and one unknown aminolipid (AL) detectable with molybdatophosphoric acid. Minor to trace amounts of two unknown phospholipids (PL2 and PL3) and three polar lipids (L1, L2 and L3) were also detected. G. tropica DSM $19535^{\mathrm{T}}$ (Supplementary Fig. S2) had DPG, PE, PC, GL and an unknown phospholipid (PL1) as major lipids, and minor amounts of an unknown phospholipid (PL2) and three polar lipids (L4, L5 and L6). Unlike G. tropica DSM 19535, strain YIM D17 ${ }^{\mathrm{T}}$ contained the lipids $\mathrm{AL}, \mathrm{L} 1, \mathrm{~L} 2$ and $\mathrm{L} 3$, but had no detectable L4, L5 or L6.

In terms of polar lipid profiles, strain YIM D $17^{\mathrm{T}}$ appeared more similar to the two strains of the genus Balneola investigated (i.e. B. vulgaris DSM $17893^{\mathrm{T}}$ and B. alkaliphila
DSM $19538^{\mathrm{T}}$ ) than to G. tropica DSM $19535^{\mathrm{T}}$ but, unlike either Balneola strain, it had PC as its major polar lipid. The major polar lipids of $B$. vulgaris DSM $17893^{\mathrm{T}}$ and $B$. alkaliphila DSM $19538^{\mathrm{T}}$ (Supplementary Fig. S2) were DPG, PG, PE, GL and an unknown polar lipid (L). The fatty acid profiles also allowed the two Balneola strains to be distinguished from strain YIM D17 ${ }^{\mathrm{T}}$ (Table 2). The $16 \mathrm{~S}$ rRNA gene sequence of the novel strain only showed a low level of similarity $(<85.0 \%)$ with the corresponding sequences of B. vulgaris DSM $17893^{\mathrm{T}}$ and B. alkaliphila DSM $19538^{\mathrm{T}}$. The polar lipids of Salisaeta longa and Salinibacter ruber have been investigated before, although those of Salisaeta longa have only previously been determined by one-dimensional TLC (Vaisman \& Oren, 2009). The lipid patterns of the investigated strains of these two species differed significantly from those of strain YIM $\mathrm{D} 17^{\mathrm{T}}$ and Gracilimonas tropica DSM $19535^{\mathrm{T}}$, especially in terms of the glycolipid and phospholipid fractions (Table 1; Vaisman \& Oren, 2009). The presence of PC in strain

Table 2. Cellular fatty acid compositions of strain YIM D1 $7^{\top}$ and the type strains of phylogenetically related species

Strains: 1, YIM D17 ${ }^{\mathrm{T}}$; 2, G. tropica DSM 19535 $; 5^{\mathrm{T}}$ 3, B. vulgaris DSM $17893^{\mathrm{T}}$; 4, B. alkaliphila DSM 19538 ${ }^{\mathrm{T}}$; 5, Salisaeta longa DSM $21114^{\mathrm{T}}$; 6, Salinibacter ruber M31 ${ }^{\mathrm{T}} ; 7$, R. marinus DSM $4252^{\mathrm{T}} ; 8$, R. profundi DSM $22212^{\mathrm{T}}$. All data are from this study except those for Salinibacter ruber $\mathrm{M} 31^{\mathrm{T}}$, which are from Peña et al. (2005). Results are presented as percentages of the total fatty acids; the major fatty acids (10\%) are highlighted in bold; fatty acids that represented $<1 \%$ in all strains are omitted. - , Not detected.

\begin{tabular}{|c|c|c|c|c|c|c|c|c|}
\hline Fatty acid & 1 & 2 & 3 & 4 & 5 & 6 & 7 & 8 \\
\hline $\mathrm{C}_{15: 0}$ & - & - & - & - & - & 2.1 & - & - \\
\hline $\mathrm{C}_{18: 0}$ & 1.4 & - & 0.1 & - & - & - & 0.2 & 0.4 \\
\hline iso- $\mathrm{C}_{13: 0}$ & 0.4 & 1.1 & 10.2 & 16.0 & 0.1 & - & - & - \\
\hline iso- $\mathrm{C}_{14: 0}$ & 1.7 & 1.1 & 15.0 & 4.1 & 0.2 & - & 3.3 & 3.2 \\
\hline anteiso- $\mathrm{C}_{15: 0}$ & 8.1 & 5.6 & 1.8 & 1.6 & 7.8 & 8.0 & 12.4 & 8.0 \\
\hline iso- $\mathrm{C}_{15: 1} \mathrm{~F}$ & 2.4 & 0.6 & 1.0 & 4.0 & 0.5 & - & - & - \\
\hline iso- $\mathrm{C}_{16: 0}$ & 3.8 & 2.6 & 6.8 & 1.8 & 6.6 & 3.9 & - & - \\
\hline iso- $\mathrm{C}_{17: 0}$ & 0.3 & 3.4 & 1.7 & 0.6 & 3.6 & - & 13.4 & 14.3 \\
\hline iso- $\mathrm{C}_{18: 0}$ & - & - & - & - & - & - & 6.8 & 7.6 \\
\hline anteiso- $\mathrm{C}_{17: 0}$ & 0.4 & 0.5 & 0.1 & - & 7.5 & - & 9.5 & 8.1 \\
\hline $\mathrm{C}_{17: 1} \omega 8 c$ & 0.5 & 5.4 & 2.8 & 1.2 & 0.8 & - & - & - \\
\hline $\mathrm{C}_{18: 1} \omega 7 c$ & - & - & - & - & 0.8 & 12.1 & - & - \\
\hline $\mathrm{C}_{18: 1} \omega 9 c$ & 4.5 & - & - & - & - & - & - & - \\
\hline anteiso- $\mathrm{C}_{17: 1} \omega 9 c$ & 1.4 & 0.8 & - & - & 1.0 & - & - & - \\
\hline 10 -methyl- $\mathrm{C}_{18: 0}$ & 3.1 & - & - & - & - & - & - & - \\
\hline $\mathrm{C}_{17: 0} 2-\mathrm{OH}$ & - & - & - & - & 0.1 & 1.6 & - & - \\
\hline iso- $\mathrm{C}_{15: 0} 2-\mathrm{OH}$ & - & - & - & - & - & $27.5^{\star}$ & - & - \\
\hline iso- $\mathrm{C}_{17: 0} 3-\mathrm{OH}$ & 0.3 & - & - & - & 0.9 & 4.1 & 0.2 & - \\
\hline $\mathrm{C}_{16: 1} \omega 7 c / \mathrm{C}_{16: 1} \omega 6 c$ & 13.8 & 8.5 & 17.2 & 14.7 & 27.2 & - & - & - \\
\hline iso- $\mathrm{C}_{17: 1} \omega 9 c / 10$-methyl- $\mathrm{C}_{16: 0}$ & 24.0 & 12.0 & 5.1 & 6.2 & - & - & - & 0.4 \\
\hline iso- $\mathrm{C}_{15: 1} \mathrm{H} / \mathrm{C}_{13: 0} 3-\mathrm{OH}$ & 0.3 & - & 0.1 & 0.5 & 8.5 & - & - & - \\
\hline
\end{tabular}

${ }^{\star}$ Reported as iso- $\mathrm{C}_{15: 0} 2-\mathrm{OH}$ and/or $\mathrm{C}_{16: 1} \omega 7 c$ by Peña et al. (2005). 
YIM D $17^{\mathrm{T}}$ distinguished it from the type strains of $R$. profundi and R. marinus (Marteinsson et al., 2010; Tindall, 1991). The major respiratory quinone of strain YIM D17 ${ }^{\mathrm{T}}$ was menaquinone-7 (MK-7). The dominant fatty acids of this strain were iso- $\mathrm{C}_{17: 1} \omega 9 c / 10$-methyl- $\mathrm{C}_{16: 0}(24.0 \%)$, iso- $\mathrm{C}_{15: 0}(23.6 \%)$ and $\mathrm{C}_{16: 1} \omega 7 c / \mathrm{C}_{16: 1} \omega 6 c(13.8 \%)$. The cellular fatty acid profile of strain YIM D17 ${ }^{\mathrm{T}}$ was similar to those of the type strains of G. tropica, B. vulgaris, B. alkaliphila and Salinibacter ruber, but clear differences could also be observed (Table 2). In terms of their fatty acid profiles, the type strains of both Rhodothermus species investigated were substantially different from strain YIM D $17^{\mathrm{T}}$ (Table 2).

Phylogenetic analysis of its almost-complete 16S rRNA gene sequence revealed that strain YIM D $17^{\mathrm{T}}$ occupied a distinct lineage with species of the genera Gracilimonas and Balneola, within the phylum Bacteroidetes (Fig. 1 and Supplementary Fig. S3). The topologies of the phylogenetic tree constructed using the neighbour-joining algorithm (Fig. 1) were similar to those of the trees constructed using the maximum-likelihood and maximum-parsimony algorithms. Sequence analysis revealed that strain YIM D $17^{\mathrm{T}}$ was closely related to G. tropica CL-CB462 ${ }^{\mathrm{T}}(85.6 \% 16 \mathrm{~S}$ rRNA gene sequence similarity), B. vulgaris 131X/A01/ $164^{\mathrm{T}}(83.0 \%)$, B. alkaliphila CM41_14b $\mathrm{b}^{\mathrm{T}}(82.8 \%)$, Salisaeta longa S4-4 $4^{\mathrm{T}}$ (77.6\%), Salinibacter ruber $\mathrm{M} 31^{\mathrm{T}}$ (77.2\%), $R$. profundi PRI $2902^{\mathrm{T}}(76.8 \%)$ and $R$. marinus DSM $4252^{\mathrm{T}}$ (76.5\%). The novel strain exhibited less than $75.0 \% 16 \mathrm{~S}$ rRNA gene sequence similarity to other established members of the phylum Bacteroidetes. No DNA-DNA hybridization experiments were performed because all the levels of $16 \mathrm{~S}$ rRNA gene sequence similarity that were observed were relatively low.
From the results of the phenotypic, chemotaxonomic, genotypic and phylogenetic analyses, strain YIM D17 $7^{\mathrm{T}}$ could not be assigned to any known taxon. Some phenotypic features (Table 1), its fatty acid (Table 2) and polar lipid profiles (Supplementary Fig. S2) and 16S rRNA gene sequence clearly differentiated this novel isolate from phylogenetically related, recognized taxa and indicated that the isolate represents a novel genus and species, for which the name Fodinibius salinus gen. nov., sp. nov. is proposed.

\section{Description of Fodinibius gen. nov.}

Fodinibius [Fo.di.ni'bi.us. L. fem. n. fodina mine; N.L. masc. n. bius from Gr. N. bios life; N.L. masc. n. Fodinibius a living (one) from a mine].

Cells are Gram-stain-negative, non-motile, moderately halophilic, non-spore-forming rods. Aerobic, catalaseand oxidase-positive. The major respiratory quinone is MK-7. The major polar lipids are diphosphatidylglycerol, phosphatidylethanolamine, phosphatidylcholine, one phospholipid, one glycolipid and one aminolipid. The dominant fatty acids are iso- $\mathrm{C}_{17: 1} \omega 9 \mathrm{c} / 10$-methyl$\mathrm{C}_{16: 0}$, iso- $\mathrm{C}_{15: 0}$ and $\mathrm{C}_{16: 1} \omega 7 c / \mathrm{C}_{16: 1} \omega 6 c$. The genus Fodinibius is a member of the phylum Bacteroidetes. The type species is Fodinibius salinus.

\section{Description of Fodinibius salinus sp. nov.}

Fodinibius salinus (sa'li.nus. L. masc. adj. salinus of or belonging to salt).

Shows the following characteristics in addition to the description given above for the genus. Colonies are pink, circular, convex and translucent, with regular margins.

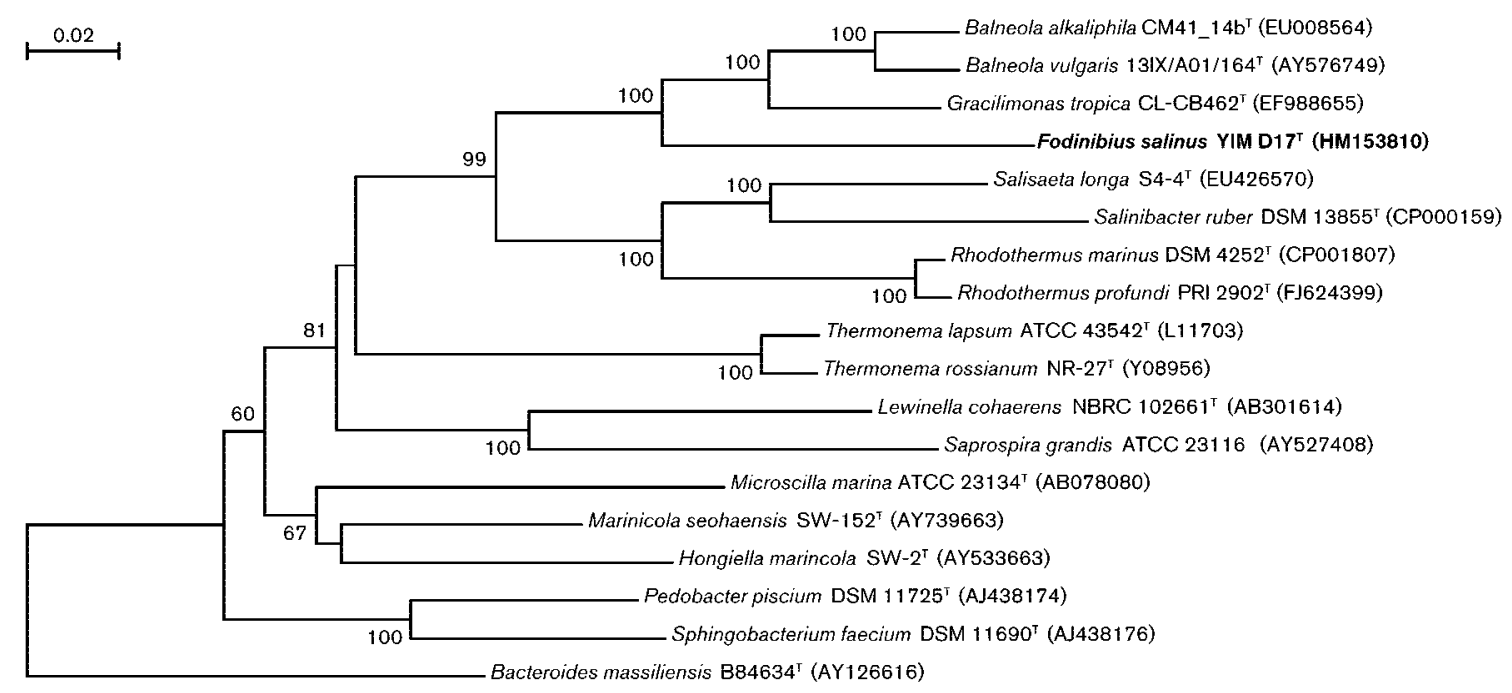

Fig. 1. Neighbour-joining tree based on 16S rRNA gene sequences showing the relationships between strain $\mathrm{YIM}^{\mathrm{D}} 17^{\top}$ and related genera. Bootstrap percentages (based on 1000 replications) $>50 \%$ are shown at branching points. Bacteroides massiliensis $B 84634^{\top}$ was used as the outgroup. Bar, 0.02 substitution per nucleotide position. 
Cells are $1.0-3.0 \mu \mathrm{m}$ in length and $0.3 \mu \mathrm{m}$ in width. Does not accumulate poly- $\beta$-hydroxybutyrate or produce bacteriochlorophyll $a$. Temperature range for growth is 25 $45{ }^{\circ} \mathrm{C}$ (optimum $37{ }^{\circ} \mathrm{C}$ ) and $\mathrm{pH}$ range for growth at $37{ }^{\circ} \mathrm{C}$ is 6.0-9.0 (optimum between 7.5 and 8.0). Growth at $37^{\circ} \mathrm{C}$ occurs at $\mathrm{NaCl}$ concentrations of $4-23 \%(\mathrm{w} / \mathrm{v})$ (optimum between 10 and $15 \%$ ). Hydrolyses aesculin, gelatin, Tween 40 and Tween 80 , but not DNA, casein or starch. Reduces nitrate to nitrite, but nitrite is not reduced. Arginine dihydrolase and urease are present. $\beta$-Galactosidase, glucose fermentation, indole production and $\mathrm{H}_{2} \mathrm{~S}$ production are absent. Assimilates citrate, aesculin and xanthine, but not acetate, aspartate, ethanol, D-galactose, glycerol, Dglucose, myo-inositol, $\alpha$-lactose, maltose, D-mannose, Dmannitol, methanol, D-sorbitol, sucrose, D-xylose, adenine, glycine or hypoxanthine. Alkaline phosphatase, esterase lipase (C8), lipase (C14), leucine arylamidase, valine arylamidase, cystine arylamidase, naphthol-AS-BI-phosphohydrolase and $N$-acetyl- $\beta$-glucosaminidase are present but esterase (C4), trypsin, $\alpha$-chymotrypsin, acid phosphatase, $\alpha$-galactosidase, $\beta$-galactosidase, $\beta$-glucuronidase, $\alpha$ glucosidase and $\beta$-glucosidase are absent. Sensitive to ampicillin $(10 \mu \mathrm{g})$, erythromycin $(15 \mu \mathrm{g})$ and chloramphenicol $(30 \mu \mathrm{g})$, but resistant to gentamicin $(10 \mu \mathrm{g})$, penicillin $\mathrm{G}(20 \mathrm{U})$, streptomycin $(10 \mu \mathrm{g})$, norfloxacin $(10 \mu \mathrm{g})$, carbenicillin $(100 \mu \mathrm{g})$ and ciprofloxacin $(5 \mu \mathrm{g})$.

The type strain YIM D17 ${ }^{\mathrm{T}}\left(=\right.$ ACCC $10716^{\mathrm{T}}=\mathrm{DSM} 21935^{\mathrm{T}}$ ) was isolated from a salt sediment collected from Fenggang salt mine $\left(23^{\circ} 28^{\prime} \mathrm{N} 100^{\circ} 43^{\prime} \mathrm{E}\right)$ in Yunnan, south-western China. The genomic DNA G $+\mathrm{C}$ content of the type strain is $43.0 \mathrm{~mol} \%$.

\section{Acknowledgements}

This work was supported by grants from the Ministry of Environmental Protection of China (National Key Sciences and Technology Program for Water Solutions, grant 2008ZX07102-004), the National Natural Science Foundation of China (NSFC) (grants 30860013, 31000003 and 31160123), the Ministry of Science and Technology of China (863 Program, grant 2007AA021306), and the Yunnan Provincial Sciences and Technology Department (grants 2005PY01-1, 2009CD012 and 2009DA002) and Yunnan University (grants 2008YB005 and 2009C14Q). We are grateful to Wei Chen, for his help during sampling, and Yun Chen, for his excellent technical assistance.

\section{References}

Alfredsson, G. A., Kristjánsson, J. K., Hjörleifsdottir, S. \& Stetter, K. O. (1988). Rhodothermus marinus gen. nov., sp. nov., a thermophilic, halophilic bacterium from submarine hot springs in Iceland. Microbiology 134, 299-306.

Allgaier, M., Uphoff, H., Felske, A. \& Wagner-Döbler, I. (2003). Aerobic anoxygenic photosynthesis in Roseobacter clade bacteria from diverse marine habitats. Appl Environ Microbiol 69, 5051-5059.

Altschul, S. F., Madden, T. L., Schäffer, A. A., Zhang, J., Zhang, Z., Miller, W. \& Lipman, D. J. (1997). Gapped BLAST and PSI-BLAST: a new generation of protein database search programs. Nucleic Acids Res 25, 3389-3402.
Antón, J., Oren, A., Benlloch, S., Rodríguez-Valera, F., Amann, R. \& Rosselló-Mora, R. (2002). Salinibacter ruber gen. nov., sp. nov., a novel, extremely halophilic member of the Bacteria from saltern crystallizer ponds. Int J Syst Evol Microbiol 52, 485-491.

Cho, J. C. \& Giovannoni, S. J. (2006). Pelagibaca bermudensis gen. nov., sp. nov., a novel marine bacterium within the Roseobacter clade in the order Rhodobacterales. Int J Syst Evol Microbiol 56, 855-859.

Choi, D. H., Zhang, G. I., Noh, J. H., Kim, W. S. \& Cho, B. C. (2009). Gracilimonas tropica gen. nov., sp. nov., isolated from a Synechococcus culture. Int J Syst Evol Microbiol 59, 1167-1172.

Cohen-Bazire, G., Sistrom, W. R. \& Stanier, R. Y. (1957). Kinetic studies of pigment synthesis by non-sulfur purple bacteria. J Cell Physiol 49, 25-68.

Collins, M. D. \& Jones, D. (1980). Lipids in the classification and identification of coryneform bacteria containing peptidoglycans based on 2,4-diaminobutyric acid. J Appl Bacteriol 48, 459-470.

Collins, M. D., Pirouz, T., Goodfellow, M. \& Minnikin, D. E. (1977). Distribution of menaquinones in actinomycetes and corynebacteria. J Gen Microbiol 100, 221-230.

Cui, X. L., Mao, P. H., Zeng, M., Li, W. J., Zhang, L. P., Xu, L. H. \& Jiang, C. L. (2001). Streptimonospora salina gen. nov., sp. nov., a new member of the family Nocardiopsaceae. Int J Syst Evol Microbiol 51, 357-363.

Felsenstein, J. (1981). Evolutionary trees from DNA sequences: a maximum likelihood approach. J Mol Evol 17, 368-376.

Felsenstein, J. (1985). Confidence limits on phylogenies: an approach using the bootstrap. Evolution 39, 783-791.

Felsenstein, J. (1993). PHYLIP (phylogeny inference package), version 3.5. Distributed by the author. Department of Genome Sciences, University of Washington, Seattle, USA.

Fitch, W. M. (1971). Toward defining the course of evolution: minimum change for a specific tree topology. Syst Zool 20, 406-416.

Gregersen, T. (1978). Rapid method for distinction of Gram-negative from Gram-positive bacteria. Eur J Appl Microbiol Biotechnol 5, 123127.

Hansen, G. H. \& Sørheim, R. (1991). Improved method for phenotypical characterization of marine bacteria. J Microbiol Methods 13, 231-241.

Kimura, M. (1980). A simple method for estimating evolutionary rates of base substitutions through comparative studies of nucleotide sequences. J Mol Evol 16, 111-120.

Kovacs, N. (1956). Identification of Pseudomonas pyocyanea by the oxidase reaction. Nature 178, 703-704.

Marteinsson, V. T., Bjornsdottir, S. H., Bienvenu, N., Kristjansson, J. K. \& Birrien, J. L. (2010). Rhodothermus profundi sp. nov., a thermophilic bacterium isolated from a deep-sea hydrothermal vent in the Pacific Ocean. Int J Syst Evol Microbiol 60, 2729-2734.

Mesbah, M., Premachandran, U. \& Whitman, W. B. (1989). Precise measurement of the $\mathrm{G}+\mathrm{C}$ content of deoxyribonucleic acid by highperformance liquid chromatography. Int J Syst Bacteriol 39, 159-167. MIDI (2005). Sherlock Microbial Identification System Operating Manual, version 6. Newark, DE: MIDI Inc.

Minnikin, D. E., Collins, M. D. \& Goodfellow, M. (1979). Fatty acid and polar lipid composition in the classification of Cellulomonas, Oerskovia and related taxa. J Appl Bacteriol 47, 87-95.

Murray, R. G. E., Doetsch, R. N. \& Robinow, F. (1994). Determinative and cytological light microscopy. In Methods for General and Molecular Bacteriology, pp. 21-41. Edited by P. Gerhardt, R. G. E. Murray, W. A. Wood \& N. R. Krieg. Washington, DC: American Society for Microbiology. 
Olsen, G. J., Woese, C. R. \& Overbeek, R. (1994). The winds of (evolutionary) change: breathing new life into microbiology. J Bacteriol 176, 1-6.

Peña, A., Valens, M., Santos, F., Buczolits, S., Antón, J., Kämpfer, P., Busse, H. J., Amann, R. \& Rosselló-Mora, R. (2005). Intraspecific comparative analysis of the species Salinibacter ruber. Extremophiles $\mathbf{9}$, $151-161$.

Saitou, N. \& Nei, M. (1987). The neighbor-joining method: a new method for reconstructing phylogenetic trees. Mol Biol Evol 4, 406-425.

Sako, Y., Takai, K., Ishida, Y., Uchida, A. \& Katayama, Y. (1996). Rhodothermus obamensis sp. nov., a modern lineage of extremely thermophilic marine bacteria. Int J Syst Bacteriol 46, 1099-1104.

Sasser, M. (1990). Identification of bacteria by gas chromatography of cellular fatty acids. USFCC Newsl 20, 16.

Smibert, R. M. \& Krieg, N. R. (1994). Phenotypic characterization. In Methods for General and Molecular Bacteriology, pp. 607-654. Edited by P. Gerhardt, R. G. E. Murray, W. A. Wood \& N. R. Krieg. Washington, DC: American Society for Microbiology.

Stoecker, K., Bendinger, B., Schöning, B., Nielsen, P. H., Nielsen, J. L., Baranyi, C., Toenshoff, E. R., Daims, H. \& Wagner, M. (2006). Cohn's Crenothrix is a filamentous methane oxidizer with an unusual methane monooxygenase. Proc Natl Acad Sci U S A 103, 2363-2367.
Tamaoka, J., Katayama-Fujimura, Y. \& Kuraishi, H. (1983). Analysis of bacterial menaquinone mixtures by high performance liquid chromatography. J Appl Bacteriol 54, 31-36.

Tamura, K., Dudley, J., Nei, M. \& Kumar, S. (2007). MEGA4: Molecular evolutionary genetics analysis (MEGA) software version 4.0. Mol Biol Evol 24, 1596-1599.

Thompson, J. D., Gibson, T. J., Plewniak, F., Jeanmougin, F. \& Higgins, D. G. (1997). The CLUSTAL_X windows interface: flexible strategies for multiple sequence alignment aided by quality analysis tools. Nucleic Acids Res 25, 4876-4882.

Tindall, B. J. (1991). Lipid composition of Rhodothermus marinus. FEMS Microbiol Lett 80, 65-68.

Urios, L., Agogué, H., Lesongeur, F., Stackebrandt, E. \& Lebaron, P. (2006). Balneola vulgaris gen. nov., sp. nov., a member of the phylum Bacteroidetes from the north-western Mediterranean Sea. Int J Syst Evol Microbiol 56, 1883-1887.

Urios, L., Intertaglia, L., Lesongeur, F. \& Lebaron, P. (2008). Balneola alkaliphila sp. nov., a marine bacterium isolated from the Mediterranean Sea. Int J Syst Evol Microbiol 58, 1288-1291.

Vaisman, N. \& Oren, A. (2009). Salisaeta longa gen. nov., sp. nov., a red, halophilic member of the Bacteroidetes. Int J Syst Evol Microbiol 59, 2571-2574. 